Kajian Malaysia, Vol. 37, No. 2, 2019, 121-145

\title{
PENGARUH KEFAHAMAN DAN PENERIMAAN RAKYAT MALAYSIA TERHADAP PERJUANGAN IDEOLOGI DAESH
}

\section{MALAYSIAN ATTITUDE AND PERCEPTION ON DAESH'S IDEOLOGICAL STRUGGLE}

\section{Che Mohd Aziz Yaacob ${ }^{1}$, Kamarulnizam Abdullah ${ }^{1 *}$ dan Mohd Sofian Omar Fauzee $^{2}$}

${ }^{1}$ School of International Studies, Universiti Utara Malaysia, Kedah, MALAYSIA

${ }^{2}$ School of Education and Modern Languages, Universiti Utara Malaysia, Kedah, MALAYSIA

*Corresponding author: kamarulnizam@uum.edu.my

Published online: 20 November 2019

To cite this article: Che Mohd Aziz Yaacob, Kamarulnizam Abdullah and Mohd Sofian Omar Fauzee. 2019. Pengaruh kefahaman dan penerimaan rakyat Malaysia terhadap perjuangan ideologi Daesh. Kajian Malaysia 37(2): 121-145. https://doi.org/10.21315/km2019.37.2.6

To link to this article: https://doi.org/10.21315/km2019.37.2.6

\begin{abstract}
ABSTRAK
Pengembangan ideologi kumpulan Daesh yang disebarkan melalui media sosial merupakan satu fenomena yang menarik dalam menganalisis radikalisme dan terorisme global masa kini. Daesh telah menggunakan pendekatan keganasan seperti pengeboman berani mati, serta penyembelihan dan pembakaran tangkapan bagi mencapai objektif politik perjuangan mereka. Ideologi kumpulan ini yang bersandarkan kepada Salafi dengan pengaruh kuat idea Wahabbi telah berkembang dari Asia Barat sehingga ke Asia Tenggara termasuk Malaysia. Kajian ini dijalankan untuk mengenal pasti sikap dan pendirian rakyat Malaysia yang beragama Islam terhadap perjuangan politik Daesh. Kajian menggunakan metode gabungan kuantitatif dan kualitatif yang dijalankan melalui pendekatan soal selidik dan focus group discussion (FGD). Sebanyak 5,232 responden dipilih secara rawak mewakili tiga sektor, iaitu keselamatan, pendidikan dan orang awam. Setiap data yang dikutip dibahagikan kepada zon utara, tengah, selatan, timur, Sabah dan Sarawak. Daripada jumlah tersebut, hanya 60 responden terpilih untuk menyertai FGD. Tahap kefahaman terhadap Daesh menunjukkan hanya 79.2\% sahaja rakyat Malaysia yang berjaya menjawab empat daripada sembilan soalan dengan betul. Kajian ini mendapati $90.8 \%$ rakyat Malaysia menolak, manakala 9.2\% lagi menerima ideologi politik Daesh. Penolakan dan penerimaan rakyat
\end{abstract}

(C) Penerbit Universiti Sains Malaysia, 2019. This work is licensed under the terms of the Creative Commons Attribution (CC BY) (http://creativecommons.org/licenses/by/4.0/). 
Malaysia dipengaruhi oleh pelbagai faktor seperti latar belakang keluarga dan pendidikan, permasalahan peribadi dan akses ke media alternatif. Walaupun peratus penolakan terhadap Daesh dilihat besar, penglibatan responden daripada dua sektor utama negara (keselamatan dan pendidikan) merupakan satu perkara yang agak membimbangkan.

Kata kunci: ideologi Daesh, terorisme, sikap, persepsi, rakyat Malaysia

\begin{abstract}
The expansion of the Daesh ideology through social media is an interesting phenomenon in analysing contemporary global radicalism and terrorism. Daesh has been using several onslaught tactics, such as suicide bombing, and slaughtering and burning people to achieve its political objectives. Based on radical Salafism with heavy influence from the Wahabbi theocratic ideas, Daesh's ideological influences have spanned from the Middle East to Southeast Asia. Malaysia is no exception. The major aim of this study is, therefore, to identify attitudes and perceptions of Malaysian Muslims on Daesh. A mixed method, qualitative and quantitative, was employed through survey and focus group discussion (FGD). Respondents were randomly selected. The survey was conducted on 5,232 Malaysians who represented three selected sectors viz. defence and security, education and the general public. The data collection is divided into six different zones: the north, south, central, and eastern region of Peninsular Malaysia, Sabah, and Sarawak. Out of that, 60 respondents were chosen as the interviewees for the FGD. The result shows that only $79.2 \%$ of the Malaysians could answer correctly four out of nine questions asked regarding their understanding of Daesh. The survey reveals that 90.8\% Malaysians rejected Daesh, while only 9.2\% accepted the group. Malaysian acceptance and rejection to Daesh has been influenced by many factors such as family and educational backgrounds, personal problems, and access to alternative media, among others. Although the majority of the respondents rejected Daesh, their association with two strategic sectors, education and security, would be a cause for concern.
\end{abstract}

Keywords: Daesh ideology, terrorism, attitude, perception, Malaysians

\title{
PENGENALAN
}

Kemunculan Daesh atau dikenali di Barat dengan pelbagai nama seperti the Islamic State of Syria and the Leviant (ISIL), the Islamic State of Syria and Iraq (ISIS), atau hanya the Islamic State (IS) merupakan satu lagi rentetan daripada pergolakan Asia 
Barat dan pengembangan terorisme bentuk baharu yang mengancam kestabilan dunia semenjak peristiwa pengeboman menara berkembar di New York pada 11 September 2001. Weiss dan Hassan $(2015,349)$ berhujah bahawa Daesh, daripada hanya sebuah kumpulan pemisah di utara Iraq yang mempunyai hubungan dengan al-Qaeda kepada satu kumpulan jihadi yang digeruni dunia, merupakan satu lagi respons dan tentangan kepada dasar Amerika Syarikat di Asia Barat. Namun bagi kebanyakan penganalisis terorisme, Daesh adalah berbeza dan lebih kejam jika dibandingkan dengan kumpulan al-Qaeda (Wright 2017; McCants 2015; Stern dan Berger 2015). Daesh bukan sahaja menentang kepada penguasaan Barat yang dilihat mengancam Islam, tetapi juga mengeluarkan "fatwa" menghalalkan serangan atau pembunuhan terhadap sesiapa sahaja termasuk negara, organisasi dan individu Islam yang dilihat bersekongkol dengan Barat dan tidak memperjuangkan agenda Islam. Walaupun pihak Barat melaporkan telah berjaya menewaskan Daesh secara ketenteraan di daerah terakhir yang dikuasainya di Baghus, Syria, namun ideologi yang dibawa oleh kumpulan tersebut terus mekar dan malar segar ke seluruh pelosok dunia termasuklah Asia Tenggara (The Guardian Online 23 Mac 2019).

Daesh yang pada mulanya dipimpin oleh Abu Musab al-Zarqawi, telah berjaya menyampaikan mesej apocalyptic dan menarik ribuan pengikut di seluruh dunia untuk sama-sama menyertai perjuangannya (McCants 2015; Small dan Hackers 2015; Warrick 2015). Malah mesej apocalyptic tersebut begitu kuat sehingga ramai dalam kalangan pejuang Daesh bukan sahaja datang dari kalangan negara Asia Barat tetapi juga dari Asia Tenggara, Afrika, Amerika dan Eropah. Di Asia Tenggara, pengaruh ideologi Daesh juga didokong oleh mereka yang taksub dengan perjuangan kumpulan tersebut (Schulze dan Liow 2018; Chan 2018; Kamarulnizam dan Ahmad 2019). Ada dalam kalangan mereka bukan sahaja sanggup merempuh kesusahan untuk sama-sama berjuang di Syria, tetapi juga membantu kumpulan Daesh untuk melancarkan serangan di rantau ini, antaranya di Marawi, Filipina pada tahun 2017.

Kejayaan Daesh yang mendapat sokongan dan dokongan segelintir umat Islam dari pelosok dunia banyak dipengaruhi oleh penggunaan media sosial sebagai alat penyampaian mesej dan propaganda. Beberapa kajian yang telah dibuat mengenai perkara ini mendapati penggunaan media sosial bukan sahaja menarik simpati segelintir umat Islam untuk menyertai perjuangan Daesh, tetapi juga telah memberikan semangat motivasi dengan dijanjikan mati syahid di atas pengorbanan mereka (Awan 2017; Jasmine 2016; Klausen 2015; Farwell 2014). Apa yang lebih menarik ialah kaum wanita dan belia tidak terkecuali daripada tertarik dan sanggup menyertai Daesh.

Beberapa kajian menunjukkan kumpulan militan Daesh mulai semakin berkembang apabila menggunakan wanita sebagai kaedah serangan bunuh diri (Loken dan Zelenz 2018; Spencer 2016; Eggert 2015; Peresin dan Cervone 2015; 
Davies 2013). Mereka menjadikan wanita sebagai senjata untuk menyerang pasukan keselamatan dan orang awam di Syria dengan memasang bom di badan dan meletupkannya. Taktik ini dilihat sangat berkesan apabila pasukan keselamatan tidak menyangka akan serangan tersebut, malah yang lebih parah apabila mereka menggunakan wanita-wanita yang sedang mengandung untuk melakukan serangan (Wan Fariza Alyati 2017). Peristiwa Pengeboman Surabaya di tiga gereja pada 13 Mei 2018 yang lalu misalnya, melibatkan aktor berani mati yang terdiri daripada ibu bapa dan anak-anak dalam satu keluarga yang sama, merupakan satu perkembangan yang amat membimbangkan. Berdasarkan kepada wacana dan persitiwa tersebut, antara faktor yang mempengaruhi mereka untuk terbabit dalam gerakan Daesh ini, khususnya wanita, adalah pengaruh suami yang sebelum ini sudah terbabit manakala pembabitan anak-anak gadis atau belia pula adalah disebabkan ingin berjihad bagi menebus dosa silam. Ada dalam kalangan mereka yang bercita-cita mati syahid kerana dapat menebus dosa selain mendapat balasan syurga.

Perubahan taktik serangan ini sangat boleh menggugat keselamatan negara sekiranya ia dilakukan di Malaysia. Pasukan keselamatan khususnya sukar untuk mengesan wanita memandangkan budaya Malaysia yang beranggapan bahawa wanita jarang terlibat dengan jenayah mahupun pengganas, bahkan yang lebih membimbangkan apabila usaha Daesh mengisytiharkan perpindahan pusat operasi mereka ke Asia Tenggara. Keadaan ini seterusnya dapat dijadikan petunjuk apabila berlaku peperangan antara pasukan Filipina dengan militan Daesh di bandar Marawi yang mengorbankan 500 nyawa dan 125 daripadanya anggota keselamatan Filipina (Franco 2017, 29). Selaras dengan itu, kumpulan militan ini menubuhkan negara khalifah Islam yang diputuskan berpusat di Mindanao dengan nama Katibah Nusantara. Lingkaran militan ini melibatkan Malaysia, Singapura, Borneo, Indonesia dan Selatan Thailand serta menyatakan kesetiaan menerima kumpulan Abu Sayyaf sebagai pemimpin Daesh di Asia Tenggara (Singh 2018; MyNewsHub 10 Jun 2017).

Melihat keadaan ini, ancaman Daesh di Malaysia kian meningkat malah boleh dianggap menjadi sasaran pada bila-bila masa (Kamarulnizam dan Ahmad 2019; Osman dan Arosoaie 2018; Ahmad Fauzi 2016; Mohd Mizan 2017; Ahmad El-Muhammady 2016). Hal ini kerana terdapat rakyat negara ini yang turut terlibat dan menyokong perjuangan ini sehingga sanggup melakukan serangan seperti yang diarahkan oleh kepimpinan Daesh yang berada di selatan Filipina. Kumpulan ini telah merancang beberapa serangan di Malaysia sebelumnya dan yang terkini adalah cubaan serangan ketika upacara sambutan penutupan Sukan SEA Kuala Lumpur (KL2017) dan serangan ke atas Perbarisan Hari Kebangsaan ke-60 di Dataran Merdeka. Walau bagaimanapun, rancangan ini dapat dipatahkan oleh Polis Diraja Malaysia (PDRM) dengan menangkap 19 lelaki yang terdiri daripada 8 warga tempatan dan 11 warga asing melalui enam siri tangkapan. 
Melalui siri tangkapan ini, pihak Bahagian Keganasan-Balas, Cawangan Khas PDRM mengeluarkan kenyataan bahawa suspek utama sebagai perancang kepada serangan ini adalah warga Filipina yang juga anggota kumpulan pengganas Abu Sayyaf yang menyusup masuk ke Sandakan, Sabah dan seterusnya ke Kuala Lumpur pada Disember 2015 (Utusan Online 5 September 2017). Penglibatan rakyat Malaysia dilihat semakin bertambah dan mula berani melakukan serangan tanpa memikirkan kesalahan dan undang-undang yang dihadapi.

Keadaan ini menunjukkan bahawa ideologi Daesh telah diresapi oleh pengikut-pengikutnya sehingga bertindak di luar batasan normal pemikiran manusia. Lebih malang apabila tindakan yang dilakukan adalah di luar batasan dan syariat Islam yang sebenar. Ideologi Daesh yang menyerapi mereka tidak lagi mampu menjadikan mereka waras apabila sanggup melakukan serangan ke atas orang awam yang tidak berdosa. Oleh itu, serangan dalam bentuk penyebaran ideologi atau kepercayaan Daesh ini sangat bahaya berbanding keganasan yang dilakukan. Kemungkinan tindakan keganasan boleh dikesan atau diatasi oleh pihak berkuasa namun ideologi tidak mampu dikesan malah sukar untuk dihapuskan. Menurut Datuk Seri Ahmad Zahid Hamidi, mantan Menteri Dalam Negeri menjelaskan pertambahan jumlah militan melibatkan rakyat Malaysia sehingga 6 Oktober 2017 adalah seramai 346 orang ditahan dengan 95 daripadanya adalah rakyat tempatan (Utusan Online 23 Oktober 2017). Jumlah yang ditahan ini walaupun nampak sedikit jika dibandingkan keseluruhan rakyat Malaysia namun cukup membimbangkan kerana ia umpama barah yang semakin merosakkan pemikiran masyarakat. Hal ini kerana penyebaran dan penerimaan ideologi berlaku secara senyap dan sukar dikesan. Ideologi yang disebarkan ini tidak memerlukan ramai pihak kerana boleh dilakukan melalui media sosial yang pastinya mempunyai pelbagai saluran yang boleh diakses oleh semua orang. Tahap keselamatan negara juga akan terjejas kerana pemikiran rakyat boleh dipengaruhi oleh ideologi Daesh pada bila-bila masa. Perkara yang lebih menakutkan berlaku apabila penyebaran ideologi ini dikaitkan dengan agama Islam yang menjadi nilai individu mahupun masyarakat. Mereka yang cetek pengetahuan agama Islam akan mudah terpengaruh pada bila-bila masa (Samuel 2012; Rahimin Affandi et al. 2016).

Realitinya, ancaman Daesh di Malaysia hari ini adalah lebih tertumpu kepada ideologi atau propaganda dengan menyebarkan doktrin-doktrin bersifat ganas melalui media sosial (Ahmad Sauffiyan 2016, 392-393). Penyebaran ideologi ini bertambah bahaya apabila mendapat sambutan rakyat Malaysia walaupun pihak berkuasa agama dan para ilmuwan agama Islam mengeluarkan pelbagai bukti kukuh penyelewengan agama yang dilakukan oleh mereka. Naratif utama Daesh adalah untuk menegakkan sebuah khalifah Islamiyah sedangkan di dalam al-Quran tidak menyatakan secara terperinci konsep kerajaan Islam yang ingin ditubuhkan. Walaupun wujud kesangsian untuk menerima saranan ini, namun Daesh mempercayai bahawa semua umat Islam wajib menyokong perjuangan 
mereka dan sesiapa yang tidak berbaiah menyokong atau menyertai perjuangan ini maka dikira berdosa serta menjadi murtad (Angkatan Tentera Malaysia 2018, 25-27). Pegangan seperti inilah yang menjadi ancaman keselamatan yang serius kepada negara. Setiap ahli yang telah direkrut boleh melakukan apa sahaja atas dasar memerangi manusia yang dilabelkan kafir termasuk orang awam yang tidak berdosa. Oleh yang demikian, menurut Dato'Ayob Khan Mydin Pitchay, Ketua Penolong Pengarah, Bahagian Keganasan-Balas Bukit Aman menjelaskan ancaman sebegini sudah wujud lebih 20 tahun kerana kita tidak fokus kepada isu pokok, iaitu penyelewengan ayat al-Quran dan pandangan ulama tetapi lebih kepada penghapusan bukti fizikal kewujudan kumpulan itu (Hashnan 2016).

Secara umumnya, ideologi yang dibawa oleh Daesh ini adalah mengikut aliran Salafi Jihadi yang menerima pandangan tokoh Islam kontroversi Ibnu Taimiyah. Pandangan dan fahaman Ibnu Taimiyah ini boleh dijadikan rujukan utama dan asas perjuangan para pendukung ekstremis dan radikalis. Dalam fahaman ini, Islam dikatakan hanya akan berdiri teguh dengan cara jihad bersenjata dan menghapuskan kerajaan yang tidak Islamik. Mereka menggunakan konsep Jihad Takfiri yang mana pengikut aliran ini digesa melaksanakan jihad dengan cara kekerasan. Konsep Jihad Takrifi ini bukan sahaja tertumpu kepada serangan terhadap bukan Islam tetapi juga kepada masyarakat atau pemimpin Islam yang dilihat gagal membawa wadah perjuangan agama. Takfiri di sini bermaksud tuduhan terhadap seorang Muslim yang lain sebagai sesat mahupun kafir kerana dilihat terpesong daripada ajaran agama, dan tidak mengamalkan Islam yang tulen. Pegangan ahli Daesh ini adalah terhad kepada ayat-ayat al-Quran dan hadis-hadis yang menyokong perjuangan mereka sahaja dan menolak mana-mana ayat al-Quran atau hadis yang tidak menyebelahi mereka. Oleh itu, mereka berpegang kepada pandangan keras dan mudah mengkafirkan orang lain (Zulkarnain 2016). Apa yang menarik, aliran ini juga membenarkan pembunuhan terhadap pemimpin atau umat Islam yang menentang kefahaman mereka mengenai Islam terutamanya di dalam pengertian jihad itu sendiri.

Pergerakan Daesh ini juga turut dikaitkan dengan kejadian-kejadian sebelum akhir zaman yang berkait rapat dengan gerakan Salafi fahaman Syed Qutb yang menjelaskan kedatangan hari kiamat. Mereka mempercayai bahawa kumpulan Daesh hari ini adalah tentera panji hitam dari timur dan akan menjadi tentera Imam Mahadi. Mereka juga yakin bahawa mereka akan menang seperti yang dijanjikan oleh Allah swT dan sangat berpegang teguh kepada hadis yang meriwayatkan siri peperangan dan pembunuhan sebelum hari kiamat (Farid 2016). Boleh didebatkan juga bahawa bukan hanya golongan Salafi "fahaman Syed Qutb" yang mempunyai keyakinan sedemikian rupa, malah pemikir Islam yang lain seperti Sheikh Imran Hossein dari Trinidad dan Ashaari Muhammad, bekas pemimpin Darul Arqam juga terkenal dengan wacana eskatologi ini, termasuklah tentang soal panji-panji hitam dari timur dan tentera Imam Mahadi. Namun yang 
menariknya mereka ini berfahaman anti-Salafi. Oleh yang demikian, objektif kajian ini adalah pertama, mengenal pasti faktor-faktor yang menyumbang kepada pengaruh IS dalam kalangan masyarakat Malaysia; kedua, mengenal pasti faktorfaktor penerima dan penolakan perjuangan IS di Malaysia, dan ketiga, mengkaji impak kefahaman rakyat Malaysia tentang IS terhadap keselamatan Malaysia.

Beberapa pengkaji telah menjalankan kajian atau penyelidikan mengenai Daesh dan impaknya kepada Malaysia (Samuel 2019; 2012; Mohd Mizan 2017; 2018; Che Mohd Aziz et al. 2016). Hasil kajian yang diketuai oleh Profesor Madya Dr Mohd Mizan Mohd Aslam contohnya, mengkaji mengenai ancaman Daesh dalam kalangan pelajar institut pengajian tinggi (IPT) di Malaysia (Muhammad Saufi 2018). Namun tidak dapat dipastikan apakah kaedah penyelidikan dan persampelan yang digunakan oleh penyelidik tersebut. Pendekatan yang paling dekat dengan kajian ini ialah penyelidikan yang dilakukan oleh Che Mohd Aziz et al. (2016). Kajian mereka merupakan kajian tinjauan terhadap pemahaman mahasiswa IPT di Malaysia. Responden kajian tersebut terdiri daripada 1,200 orang mahasiswa bertaraf belia. Namun fokus, konteks, analisis dan kumpulan sasaran kajian ini adalah lebih besar dengan tumpuan kepada mereka yang bekerja di sektor pendidikan, pertahanan dan orang awam. Dua sektor pertama adalah penting kerana ia melibatkan isu keamanan, pembangunan dan pembinaan negara-bangsa. Di samping itu, pendekatan kualitatif dan kuantitatif serta teknik trangulasi yang digunakan dalam kajian ini untuk mengabsahkan data tidak pernah digunakan oleh kajian-kajian sebelum ini.

\section{METODOLOGI}

\section{Kaedah Penyelidikan}

Bagi merungkai fenomena ini, satu kajian telah dijalankan untuk mengenal pasti tahap penerimaan dan penolakan rakyat Malaysia yang beragama Islam terhadap ideologi militan Daesh ini. Metodologi kajian menggunakan gabungan kaedah kuantitatif dan kualitatif meliputi penggunaan borang soal selidik, temu bual dan FGD. Kaedah kualitatif digunakan bagi memantapkan lagi data kuantitatif yang dikutip khususnya berkaitan dengan persepsi dan pandangan masyarakat yang tidak boleh dikira.

\section{Persampelan}

Memandangkan kajian ini adalah kaedah gabungan antara kuantitatif dan kualitatif, persampelannya terbahagi kepada dua, iaitu (1) persampelan kuantitatif dan (2) persampelan berfokus melalui FGD. 


\section{Persampelan kuantitatif}

Sejumlah 5,232 orang responden beragama Islam telah dipilih secara rawak yang terdiri daripada tiga agensi yang berbeza iaitu staf agensi keselamatan, pendidikan dan orang awam. Bagi sektor keselamatan, jabatan yang dipilih melibatkan tentera dan agensi-agensi di bawah Kementerian Dalam Negeri melibatkan Jabatan Penjara, Jabatan Imigresen dan Agensi Kawalan Sempadan Malaysia (AKSEM). Sektor pendidikan pula terdiri daripada pensyarah, staf dan pelajar universiti serta guru, staf dan pelajar sekolah menengah. Responden daripada kalangan orang awam yang dipilih secara rawak terdiri daripada mereka yang bekerja sendiri, industri, peniaga, suri rumah dan belia.

\section{Persampelan kualitatif}

Seramai 60 orang responden yang juga beragama Islam berumur antara 20 hingga 45 tahun telah bersetuju untuk menyertai FGD. Selain diberi borang soal selidik, FGD juga diadakan menerusi teknik temu bual. Kawasan penyelidikan pula melibatkan seluruh Malaysia yang dibahagikan kepada enam zon, iaitu utara, tengah, selatan, timur, Sabah dan Sarawak.

\section{Instrumen Kajian}

Kaedah gabungan ini memerlukan dua instrumentasi yang berbeza, iaitu (1) instrumen kajian kuantitatif dan (2) instrumen kajian kualitatif. Kedua-dua instrumen tersebut dijelaskan secara terperinci seperti berikut.

\section{Instrumen kajian kuantitatif}

Instrumen kajian ini telah diadaptasi daripada instrumen asal yang dibina oleh Che Mohd Aziz et al. (2016). Hasil daripada kajian rintis mendapati bahawa soal selidik adalah sesuai dengan alfa Cronbach untuk penerimaan Daesh $\alpha=0.89$. Dalam kajian sebenar $\alpha=0.90$. Soalan yang berbentuk negatif (penolakan) akan dilakukan reverse score seperti soalan "Ideologi dan perjuangan Daesh sesuai dalam masyarakat majmuk di Malaysia".

\section{Instrumen kajian kualitatif}

Soal selidik dibina oleh penyelidik bagi menjawab objektif kajian. Antara soalan yang diajukan kepada responden adalah seperti berikut:

1. Kefahaman tentang pertubuhan IS 
a. Apakah yang dikatakan sebagai pertubuhan IS ini?

b. Kenapakah IS ditubuhkan?

c. Apakah nama asal IS ini dan siapakah pengasas pertubuhan ini?

d. Kenapakah kerajaan memerangi IS ini?

e. Adakah IS hanya satu kumpulan sahaja atau banyak kumpulan?

f. Apakah yang dilakukan oleh anggota IS di peringkat antarabangsa dan Malaysia?

g. Apakah tujuan mereka melakukan aktiviti keganasan?

2. Faktor-faktor yang menjadi potensi kepada penolakan

a. Adakah IS merupakan pertubuhan pengganas dan siapakah yang melabelkannya?

b. Kenapakah IS menjadi ancaman kepada rakyat Malaysia?

c. Adakah benar IS merupakan pertubuhan pengganas yang dibentuk oleh kumpulan tertentu untuk menghancurkan umat Islam?

d. Saya percaya bahawa akan wujud perjuangan Islam yang sebenar bagi melawan atau menghapuskan IS pada hari ini.Ya atau tidak, kenapa?

\section{Prosedur Kajian}

Prosedur kajian ini akan mengikut proses yang sistematik bagi memastikan bahawa kaedah metode campuran (mixed-method) ini dapat dilaksanakan dengan teratur, menyeluruh dan efisien.

1. Mendapatkan surat pelantikan sebagai penyelidik daripada pihak Institut Keselamatan Awam Malaysia (IPSOM) bagi menjalankan kajian ini.

2. Melalui surat Ketua Setiausaha KDN, pihak IPSOM akan memohon kebenaran untuk menjalankan kajian terhadap kakitangan kerajaan yang terlibat seperti Kementerian Pelajaran Malaysia, Kementerian Pengajian Tinggi, Kementerian Pertahanan, Polis, Imigresen, Jabatan Pertahanan Awam Malaysia (JPAM), dan Unit Pencegahan Penyeludupan (UPP) atau dikenali sekarang sebagai AKSEM. Begitu juga kebenaran daripada Kerajaan Negeri bagi menjalankan kajian terhadap sekolah agama dan pondok di bawah kawalan Kerajaan Negeri. 
3. Semasa proses memohon kebenaran daripada pihak yang terlibat, penyelidik akan menyediakan soal selidik tinjauan dan soalan FGD serta melakukan kajian rintis bagi memastikan bahawa soal selidik dan soalan FGD sudah bersedia untuk diedarkan di samping memastikan kesesuaian dengan kajian ini.

4. Bagi Kajian 1 dan 2, tinjauan dan FGD akan dilakukan melibatkan enam zon, iaitu Zon 1: Utara, Zon 2: Selatan, Zon 3: Tengah, Zon 4: Timur, Zon 5: Sabah, dan Zon 6: Sarawak. Kedua-dua kajian ini berjalan serentak dengan tinjauan (soal selidik). Bagi masyarakat umum dan kakitangan kerajaan, responden akan dijemput secara rawak seramai 10 orang bagi setiap kawasan yang mewakili institusi masing-masing. Proses FGD akan dijalankan sebanyak sekali sahaja bagi setiap zon melibatkan kumpulan yang berbeza latar belakang sejajar dengan sampel yang dibentuk. Kesemua responden perlu menandatangani surat kebenaran untuk dirakam segala perbualan dalam kajian FGD.

\section{Analisis Data}

Bagi kajian kualitatif, analisis data trangulasi menggunakan perisian IBM SPSS 24.0 dengan menggunakan statistik deskriptif bagi mendapatkan angka yang jelas dan mudah untuk penerimaan masyarakat umum. Manakala bagi data kualitatif pula, hujah sebenar yang disuarakan oleh responden menjadi bahan untuk menyokong dapatan tersebut.

\section{DAPATAN KAJAN}

\section{Demografi Responden}

Jadual 1 menunjukkan demografi responden secara keseluruhan mengikut kategori anggota keselamatan, orang awam dan sektor pendidikan. 
Jadual 1: Demografi mengikut kategori responden

\begin{tabular}{|c|c|c|c|c|c|c|c|c|}
\hline & \multicolumn{2}{|c|}{$\begin{array}{c}\text { Anggota } \\
\text { keselamatan }\end{array}$} & \multicolumn{2}{|c|}{ Orang awam } & \multicolumn{2}{|c|}{ Sektor pendidikan } & \multicolumn{2}{|c|}{ Jumlah } \\
\hline & Bil & $\%$ & Bil & $\%$ & Bil & $\%$ & Bil & $\%$ \\
\hline \multicolumn{9}{|l|}{ Jantina } \\
\hline Lelaki & 1,059 & 20.2 & 726 & 13.9 & 1,210 & 23.1 & 2,995 & 57.2 \\
\hline Perempuan & 388 & 7.4 & 633 & 12.1 & 1,216 & 23.2 & 2,237 & 42.8 \\
\hline Jumlah & 1,447 & 27.7 & 1,359 & 26.0 & 2,426 & 46.4 & 5,232 & 100 \\
\hline \multicolumn{9}{|l|}{ Umur } \\
\hline 20 ke bawah & 4 & 0.1 & 63 & 1.2 & 1,056 & 20.2 & 1,123 & 21.5 \\
\hline $21-30$ & 454 & 8.7 & 621 & 11.9 & 687 & 13.1 & 1,762 & 33.7 \\
\hline $31-40$ & 653 & 12.5 & 324 & 6.2 & 374 & 7.1 & 1,351 & 25.8 \\
\hline $41-50$ & 208 & 4.0 & 225 & 4.3 & 221 & 4.2 & 654 & 12.5 \\
\hline $51 \mathrm{ke}$ atas & 128 & 2.42 & 126 & 2.4 & 88 & 1.7 & 342 & 6.5 \\
\hline Jumlah & 1,447 & 27.7 & 1,365 & 26.0 & 2,426 & 46.4 & 5,238 & 100 \\
\hline \multicolumn{9}{|l|}{ Status } \\
\hline Bujang & 259 & 5.0 & 584 & 11.2 & 1,741 & 33.3 & 2,584 & 49.4 \\
\hline Berkahwin & 1,155 & 22.1 & 719 & 13.6 & 662 & 12.7 & 2,536 & 48.4 \\
\hline Duda/Janda & 33 & 0.6 & 62 & 1.2 & 23 & 0.4 & 118 & 2.3 \\
\hline Jumlah & 1,447 & 27.7 & 1,359 & 26.0 & 2,426 & 46.4 & 5,232 & 100 \\
\hline \multicolumn{9}{|l|}{ Zon Kajian } \\
\hline Sabah & 66 & 1.3 & 241 & 4.6 & 449 & 8.6 & 756 & 14.4 \\
\hline Sarawak & 0 & 0 & 143 & 2.7 & 427 & 8.2 & 570 & 10.9 \\
\hline Selatan & 17 & 0.3 & 360 & 6.9 & 412 & 7.9 & 789 & 15.1 \\
\hline Tengah & 698 & 13.3 & 269 & 5.1 & 234 & 4.5 & 1,201 & 23.0 \\
\hline Timur & 139 & 2.7 & 193 & 3.7 & 333 & 6.4 & 665 & 12.7 \\
\hline Utara & 527 & 10.1 & 153 & 2.9 & 571 & 10.9 & 1,251 & 23.9 \\
\hline Jumlah & 1,447 & 27.7 & 1,359 & 26.0 & 2,426 & 46.4 & 5,232 & 100 \\
\hline \multicolumn{9}{|l|}{ Tahap Pendidikan } \\
\hline $\begin{array}{l}\text { Tidak } \\
\text { bersekolah }\end{array}$ & 0 & 0 & 3 & 0.1 & 1 & 0.0 & 4 & 0.1 \\
\hline Tamat Darjah 6 & 0 & 0 & 10 & 0.2 & 90 & 1.7 & 100 & 1.9 \\
\hline $\begin{array}{l}\text { LCE/SRP/ } \\
\mathrm{PMR} / \mathrm{PT} 3\end{array}$ & 66 & 1.3 & 111 & 2.1 & 451 & 8.6 & 628 & 12.0 \\
\hline
\end{tabular}


Che Mohd Aziz Yaacob et al.

Jadual 1: (sambungan)

\begin{tabular}{|c|c|c|c|c|c|c|c|c|}
\hline & \multicolumn{2}{|c|}{$\begin{array}{c}\text { Anggota } \\
\text { keselamatan }\end{array}$} & \multicolumn{2}{|c|}{ Orang awam } & \multicolumn{2}{|c|}{ Sektor pendidikan } & \multicolumn{2}{|c|}{ Jumlah } \\
\hline & Bil & $\%$ & Bil & $\%$ & Bil & $\%$ & Bil & $\%$ \\
\hline SPM/SPAM & 851 & 16.3 & 617 & 11.8 & 448 & 8.6 & 1,916 & 36.6 \\
\hline $\begin{array}{l}\text { STPM/STAM/ } \\
\text { DIP }\end{array}$ & 367 & 7.0 & 328 & 6.3 & 810 & 15.5 & 1,505 & 28.8 \\
\hline Ijazah Pertama & 104 & 2.0 & 196 & 3.7 & 384 & 7.3 & 684 & 13.1 \\
\hline Ijazah Sarjana & 57 & 1.1 & 52 & 1.0 & 91 & 1.7 & 200 & 3.8 \\
\hline $\mathrm{PhD}$ & 2 & 0.0 & 4.2 & 0.8 & 151 & 2.9 & 195 & 3.7 \\
\hline Jumlah & 1,447 & 27.7 & 1,359 & 26.0 & 2,426 & 46.4 & 5,232 & 100 \\
\hline \multicolumn{9}{|l|}{ Pendidikan Agama } \\
\hline Formal & 1,210 & 23.1 & 1,066 & 20.4 & 1,945 & 37.2 & 4,221 & 80.7 \\
\hline Tidak formal & 237 & 4.5 & 293 & 5.6 & 481 & 9.2 & 1,011 & 19.3 \\
\hline Jumlah & 1,447 & 27.7 & 1,359 & 26.0 & 2426 & 46.4 & 5,232 & 100 \\
\hline \multicolumn{9}{|l|}{$\begin{array}{l}\text { Pendidikan Agama } \\
\text { Formal }\end{array}$} \\
\hline $\begin{array}{l}\text { Sekolah } \\
\text { Kebangsaan }\end{array}$ & 1,218 & 23.3 & 1,149 & 22.0 & 1,514 & 28.9 & 3,881 & 74.2 \\
\hline $\begin{array}{l}\text { Sekolah } \\
\text { Agama } \\
\text { Kerajaan }\end{array}$ & 217 & 4.1 & 169 & 3.2 & 749 & 14.3 & 1,135 & 21.7 \\
\hline $\begin{array}{l}\text { Sekolah } \\
\text { Agama } \\
\text { Rakyat@ } \\
\text { swasta }\end{array}$ & 1 & 0.0 & 12 & 0.2 & 41 & 0.8 & 54 & 3.1 \\
\hline $\begin{array}{l}\text { Madrasah@ } \\
\text { pondok }\end{array}$ & 11 & 0.2 & 29 & 0.6 & 122 & 2.3 & 162 & 1.0 \\
\hline Jumlah & 1,447 & 27.7 & 1,359 & 26.0 & 2,426 & 46.4 & 5,232 & 100 \\
\hline \multicolumn{9}{|l|}{$\begin{array}{l}\text { Pendidikan Agama } \\
\text { Tidak Formal }\end{array}$} \\
\hline Keluarga & 1,027 & 19.6 & 1,121 & 21.4 & 2,118 & 40.5 & 4,266 & 81.5 \\
\hline Masjid@surau & 328 & 6.3 & 141 & 2.7 & 189 & 3.6 & 658 & 12.6 \\
\hline Rakan-rakan & 26 & 0.5 & 48 & 0.9 & 45 & 0.9 & 119 & 2.3 \\
\hline $\begin{array}{l}\text { Internet/Media } \\
\text { sosial }\end{array}$ & 59 & 1.1 & 32 & 0.6 & 47 & 0.9 & 138 & 2.6 \\
\hline Lain-lain & 7 & 0.1 & 17 & 0.3 & 27 & 0.5 & 51 & 1.0 \\
\hline Jumlah & 1,447 & 27.7 & 1,359 & 26.0 & 2,426 & 46.4 & 5,232 & 100 \\
\hline
\end{tabular}




\section{Kefahaman, Pengetahuan dan Faktor Mempengaruhi Sokongan Rakyat Malaysia terhadap Daesh}

Rakyat Malaysia umumnya mendapat maklumat tentang Daesh melalui saluran televisyen dan surat khabar melalui paparan siri serangan mahupun tangkapan oleh PDRM. Saluran asas ini adalah kaedah yang biasa digunakan oleh kerajaan untuk penyampaian maklumat kepada masyarakat. Namun begitu, masyarakat boleh memilih pelbagai saluran media sosial untuk mendapatkan maklumat tentang Daesh sehingga ada yang terperangkap dan terpengaruh dengan ideologi kelompok pengganas ini. Kefahaman dan pengetahuan tentang Daesh boleh mempengaruhi seseorang untuk menyokong perjuangan Daesh. Kefahaman yang kurang mendalam akan menjadi faktor kebarangkalian seseorang itu menyokong Daesh. Keadaan ini pastinya menggusarkan pihak kerajaan sekiranya ramai dalam kalangan rakyat Malaysia tidak faham dan berpengetahuan tentang Daesh. Data kajian menunjukkan bahawa daripada 5,232 orang responden yang melibatkan anggota keselamatan, orang awam dan sektor pendidikan, didapati hanya seorang sahaja yang menjawab dengan betul daripada lapan soalan yang dikemukakan tentang Daesh. Secara keseluruhannya 4,146 (79.2\%) responden telah berjaya menjawab sekurang-kurangnya empat soalan yang betul. Manakala $66(1.3 \%)$ responden yang mampu menjawab satu soalan dengan betul. Data ini menunjukkan tahap kefahaman rakyat Malaysia terhadap Daesh masih lagi rendah walaupun berita tentang insiden Daesh kerap dipaparkan di pelbagai saluran media. Walaupun pelbagai usaha oleh pihak tertentu untuk menerapkan nilai kefahaman kepada rakyat tentang Daesh namun penerimaan rakyat masih lagi di tahap yang lemah. Jadual 2 dan Rajah 1 menunjukkan tahap pengetahuan dan kefahaman responden terhadap Daesh.

\section{Penerimaan dan Penolakan Rakyat Malaysia Terhadap Ideologi dan Perjuangan Daesh}

Malaysia merupakan sebuah negara yang berbilang kaum dan rakyatnya mempunyai pelbagai latar belakang yang berbeza. Tahap pemikiran dan penilaian bagi setiap orang adalah berbeza dan berkemungkinan akan membawa keburukan sekiranya tidak diselaraskan dengan baik. Penerimaan segelintir individu terhadap ideologi dan perjuangan Daesh merupakan salah satu ancaman keselamatan yang berpotensi di Malaysia. Walaupun penerimaan ini tidak serius, ia boleh membimbangkan pihak kerajaan kerana mereka yang menerima atau menyokong Daesh ini berpotensi mempengaruhi orang lain jika tidak dibendung. Mereka yang terlibat dalam perjuangan Daesh pasti akan mencari pengaruh kerana asas perjuangan dan strategi mereka adalah menggunakan agama Islam yang dimanipulasi untuk mendapatkan sokongan. 


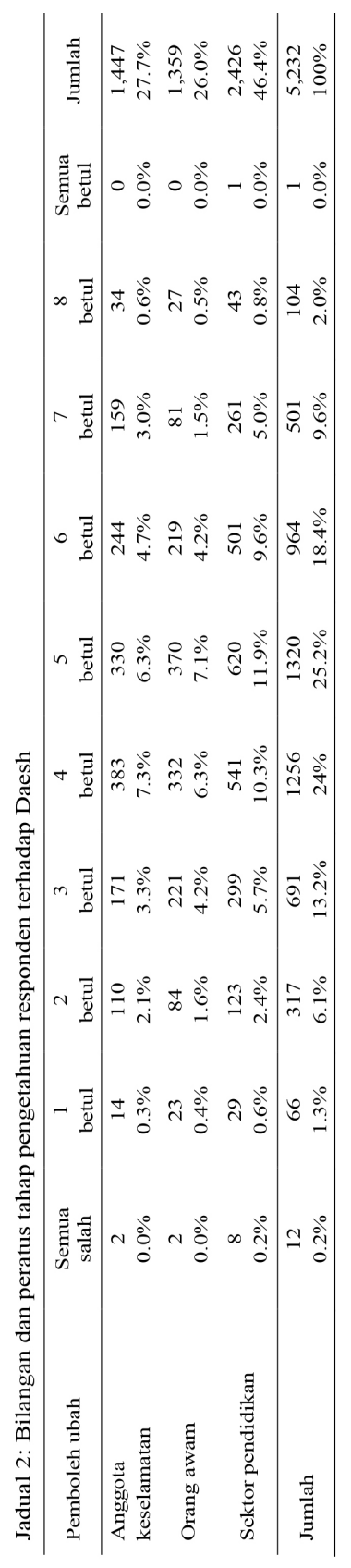




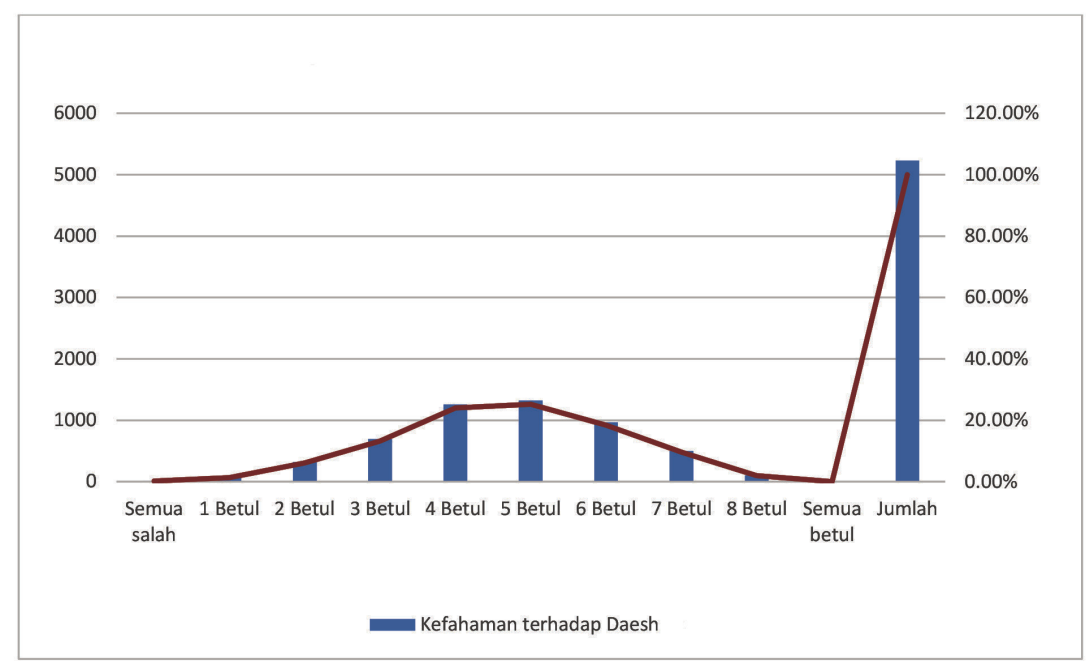

Rajah 1: Kefahaman terhadap Daesh

Berdasarkan Jadual 3 dan Rajah 2, dapatan kajian menunjukkan daripada empat skala $(1-1.75,1.76-2.5,2.51-3.25,3.26-4.00)$ yang diberikan, didapati bahawa 480 (9.2\%) daripada jumlah keseluruhan responden bersetuju untuk menerima perjuangan Daesh. Daripada jumlah yang menerima perjuangan Daesh, $100(1.9 \%)$ responden sangat bersetuju menerima Daesh. Daripada jumlah keseluruhan sangat bersetuju itu, sebanyak $46(0.9 \%)$ dan $45(0.9 \%)$ responden daripada orang awam dan sektor pendidikan, manakala anggota keselamatan hanya menyumbang sebanyak $9(0.2 \%)$ responden sahaja.

Jadual 3: Bilangan dan peratus mengikut kategori responden tentang penerimaan responden terhadap perjuangan Daesh secara keseluruhan

\begin{tabular}{lccccc}
\hline $\begin{array}{l}\text { Pemboleh } \\
\text { ubah }\end{array}$ & $\begin{array}{c}\text { Sangat tidak } \\
\text { setuju }\end{array}$ & Tidak setuju & Setuju & Sangat setuju & Jumlah \\
\hline Anggota & 1,093 & 313 & 32 & 9 & 1,447 \\
keselamatan & $20.9 \%$ & $6.0 \%$ & $0.6 \%$ & $0.2 \%$ & $27.7 \%$ \\
Orang awam & 762 & 360 & 191 & 46 & 1,359 \\
& $14.6 \%$ & $6.9 \%$ & $3.7 \%$ & $0.9 \%$ & $26.0 \%$ \\
Sektor & 1,639 & 585 & 157 & 45 & 2,426 \\
pendidikan & $31.3 \%$ & $11.2 \%$ & $3.0 \%$ & $0.9 \%$ & $46.4 \%$ \\
\hline Jumlah & 3,494 & 1,258 & 380 & 100 & 5,232 \\
& $66.8 \%$ & $24.0 \%$ & $7.3 \%$ & $1.9 \%$ & $100 \%$ \\
\hline
\end{tabular}




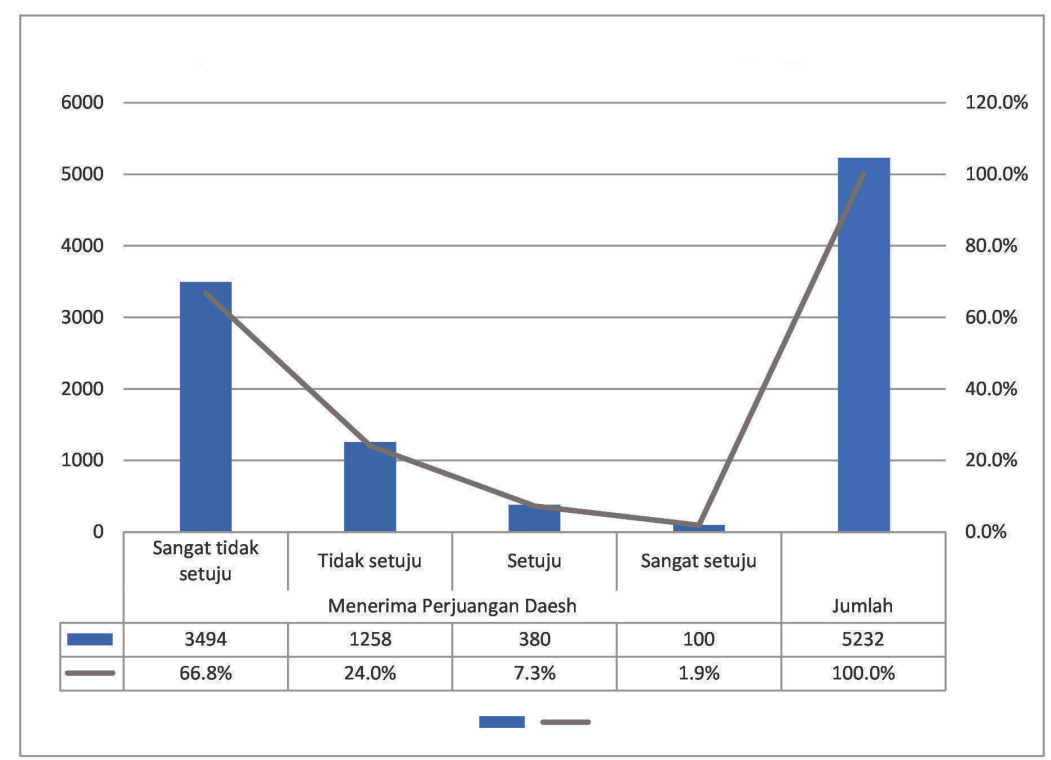

Rajah 2: Penerimaan perjuangan Daesh secara keseluruhan

\section{PERBINCANGAN}

Makalah ini membawa pembaca memahami dua aspek utama yang dipilih daripada hasil kajian. Pertama, membincangkan dari sudut kefahaman rakyat Malaysia terhadap perjuangan Daesh dan kedua melihatkan kepada penerimaan rakyat Malaysia terhadap ideologi dan perjuangan Daesh. Setiap perbincangan akan diselitkan dengan data kuantitatif berbentuk jadual atau rajah peratusan di samping menambah baik perbincangan dengan penambahan data-data FGD dan temu bual.

\section{Kefahaman Terhadap Daesh}

Walaupun $79.2 \%$ responden (Jadual 1) mampu menjawab empat daripada sembilan soalan tentang kefahaman mereka terhadap Daesh, merujuk kepada data FGD masih terdapat kelemahan pengetahuan ini yang bersifat ilmiah dan saintifik yang memerlukan bacaan yang mendalam. Contohnya, seperti sejarah, latar belakang, strategi, aktor, pemimpin dan kawasan. Sebagai rakyat biasa, kebanyakan mereka hanya mengambil tahu tentang Daesh di peringkat asas sahaja. Sebagai contoh, salah seorang responden menceritakan tentang kefahaman mereka seperti berikut: 
Pada pandangan saya, IS di Malaysia ini belum lagi sampai pada tahap yang membimbangkan. Sebab di Malaysia ramai yang sedar IS ini bukanlah satu kumpulan yang bagus untuk kita ikut. Seperti yang kita tengok pada masa ini di media massa tersebar keburukan IS. Jadi ramai rakyat Malaysia yang sedar keburukan IS. Seperti no.1 (responden lain) kata, cuma ada segelintir yang terpengaruh dengan IS ini yang kebanyakan kurang mempunyai/mendalami ilmu agama.

Hal ini jelas menunjukkan bahawa kurangnya kefahaman ilmu terhadap agama dan Daesh boleh mempengaruhi seseorang itu. Hasil dapatan kajian ini juga menguatkan lagi kenyataan-kenyataan yang dikeluarkan oleh polis, pemimpin agama dan pemimpin politik di Malaysia sebelum ini bahawa kebanyakan mereka yang terlibat dengan Daesh sebenarnya mempunyai pengetahuan yang cetek tentang agama Islam. Mereka tidak pernah berguru dengan guru agama yang diiktiraf dan mendalami Islam melalui pembacaan sendiri dan melalui Internet. Menurut Penolong Pengarah, Bahagian Keganasan-Balas, Cawangan Khas Bukit Aman, SAC Dato' Ayub Khan Mydin Pitchay, kebanyakan daripada mereka yang terlibat dengan Daesh adalah belia dan pelajar:

... yang mempunyai masalah keluarga serta cetek pengetahuan agama; mudah terpengaruh dengan fahaman kumpulan itu apabila dijanjikan dengan tawaran seperti mati syahid (jalan singkat ke syurga) serta boleh berkahwin secara mutaah.

Oleh yang demikian, beliau menyarankan golongan cerdik pandai agama berganding bahu untuk memberikan penerangan yang jelas mengenai beberapa konsep dalam Islam seperti hijrah dan jihad agar masyarakat Islam yang kurang didikan agama faham perkara yang dilakukan oleh Daesh itu bukan yang dituntut oleh Islam (Portal Rasmi Polis Diraja Malaysia 2016).

Walau bagaimanapun, terdapat segelintir yang mempunyai pendirian sendiri dan lemah dalam memahami perjuangan Daesh. Ada di antara mereka yang tidak langsung memahami konsep Daesh (1.3\%) dan hanya mampu menjawab satu soalan dengan betul. Kelemahan ini akan memberi kesan jika tidak dikawal apabila rakyat Malaysia boleh dipengaruhi dan dimanipulasi oleh ahli Daesh untuk menjadi ahli atau sekurang-kurangnya menyokong perjuangan mereka. Kenyataan ini dipersetujui oleh responden dari utara:

Seperti yang kita tengok mereka yang menyertai Daesh ini golongan yang baru nak kenal Islam di kalangan golongan kebanyakan dan bukan dari golongan cendiakawan. Sebab di Malaysia masyarakat di sini lebih memikirkan kejadian ataupun benda-benda yang patut diutamakan, itu orang yang cerdik. Tetapi kebanyakan yang menyertai Daesh ini tak cerdik pun sebenarnya, pengetahuan ilmu pun kurang sebab itu sertai IS ini. 
Secara umumnya, kebanyakan responden memahami isu Daesh ini sejajar dengan pendirian kerajaan Malaysia, iaitu Daesh merupakan pertubuhan pengganas yang menjadikan agama Islam sebagai alat untuk mencapai kepentingan politik. Responden juga memahami perkara ini seperti dalam petikan di bawah:

Kelompok ini menjadikan persenjataan sebagai wadah perjuangan malahan tidak sejajar dan memenuhi syariat Islam dalam berhadapan dengan kelompok yang dianggap musuh. Tindakan menyembelih manusia, membakar hidup-hidup, membunuh kanak-kanak, orang tua dan tempat ibadat adalah sesuatu yang dilarang oleh Islam tetapi dilakukan oleh militan Daesh.

Jika diamati, pendekatan Daesh ini juga telah memburukkan lagi imej Islam di mata dunia dan mewujudkan Islamofobia. Dalam ajaran Islam, apabila umat Islam berperang, adalah dilarang melakukan kekejaman terhadap orang awam terutamanya kanak-kanak dan wanita, harta benda dan tumbuh-tumbuhan. Tetapi apa yang dilakukan oleh militan Daesh telah melangkaui syarat tersebut dengan menjadikan kanak-kanak dan wanita sebagai mangsa mereka juga.

Kebanyakan responden faham bahawa kurang mempunyai ilmu agama adalah punca terpengaruh dengan perjuangan Daesh. Hasil dapatan ini juga memperkuatkan kajian serta laporan terdahulu yang menunjukkan bahawa kedaifan dalam memahami asas ajaran Islam telah menyebabkan ramai rakyat Malaysia terpengaruh dengan ideologi Daesh (Nacim 2016, 14; Daily Sabah 16 Ogos 2016).

\section{Penerimaan Terhadap Daesh}

Berdasarkan Rajah 2, maksud bagi jawapan "sangat tidak setuju" dan "tidak setuju" adalah responden yang menolak perjuangan Daesh manakala yang "setuju" dan "sangat setuju" merujuk kepada responden yang menerima dan menyokong perjuangan militan ini. Data yang diperoleh menunjukkan sebanyak 66.8\% (sangat tidak setuju) dan $24 \%$ (tidak bersetuju) responden yang menolak perjuangan Daesh. Jumlah ini sangat tinggi berbanding responden yang menerima perjuangan Daesh, iaitu 7.3\% (setuju) dan 1.9\% (sangat setuju). Angka ini berkurangan 3.4\% sebagaimana yang dilaporkan pada tahun 2015 oleh Poushter (2015). Walaupun data menunjukkan lebih 66\% rakyat Malaysia menolak Daesh, namun kita tidak boleh memandang ringan kepada mereka yang menunjukkan kecenderungan menyokong perjuangan dan ideologi kumpulan tersebut (9.2\%). Hal ini kerana mereka yang menjadi responden kepada kajian ini terdiri daripada sektor yang amat kritikal dalam pembangunan dan pengurusan negara, iaitu keselamatan dan pendidikan. Mereka yang terlibat dalam sektor keselamatan adalah mereka yang sepatutnya melindungi negara ini daripada anasir subversif yang boleh merosakkan 
negara, manakala kehadiran kumpulan minoriti dalam sektor pendidikan boleh menjejaskan pembangunan sahsiah dan minda remaja dan guru. Oleh itu, kajian ini berpendapat bahawa golongan minoriti yang radikal boleh memberi kesan kepada kestabilan sesebuah negara. Sejarah telah menunjukkan bahawa golongan pemisah, militan atau teroris di kebanyakan negara seperti Indonesia, Pakistan dan India, merupakan kumpulan minoriti namun mampu menjejaskan keselamatan ekonomi dan politik negara yang terbabit. Di Pakistan, misalnya, ancaman berterusan kumpulan militan Islam telah memberi kesan kepada ekonomi negara tersebut dari segi peningkatan kemiskinan yang ketara, hilangnya kemasukan pelaburan luar, kemusnahan insfrastruktur, dan pengurangan dana awam. Pertumbuhan keluaran dalam negara kasar (KDNK) di Pakistan hanya sekitar 1.6\% pada tahun 2010 apabila ancaman militan dan terrorisme berada di kemuncaknya (Hyder, Akram dan Padda 2015, 715).

Hasil dapatan kajian ini juga menunjukkan bahawa Malaysia tidak dapat lari daripada serangan Daesh sekiranya tiada kawalan ketat dilakukan bagi menggagalkan pengaruh Daesh terhadap rakyat Malaysia. Penolakan responden terhadap perjuangan Daesh adalah disebabkan kefahaman mereka terhadap agama Islam yang agak mendalam, iaitu mereka boleh membezakan antara ajaran Islam sebenar yang bercanggah dengan apa yang dilakukan oleh kumpulan Daesh. Contohnya, seorang responden daripada Sabah menerangkan bahawa:

Sebagai seorang Muslim, Islam tidak mengajar kita sebagaimana yang mereka (Daesh) buat. Sebab kita ada satu peraturan yang telah ditetapkan dan juga undang-undang yang telah dipersetujui oleh semua. Jadi membunuh, memancung manusia dan memukul ini di luar daripada perikemanusiaan.

Namun perhatian harus juga diberikan kepada mereka yang menyokong perjuangan Daesh. Pihak yang terbabit perlu menjalankan program berbentuk informasi dan counter-narrative secara berterusan kepada kumpulan sasar dalam sektor keselamatan dan pendidikan bagi memastikan ideologi Daesh tidak mempunyai ruang untuk mempengaruhi minda dan persepsi mereka.

Ada sesetengahnya berpendapat bahawa Daesh adalah perjuangan politik kekerasan dengan menjadikan agama Islam sebagai alat untuk mendapatkan pengaruh dan sokongan. Namun begitu, terdapat responden yang berpendirian dua keadaan, iaitu menyokong dan menolak. Data FGD menjelaskan bahawa sesetengah responden menyokong dan bersetuju dengan Daesh apabila kumpulan ini cuba untuk membawa sistem pemerintahan khalifah yang berteraskan Islam dan cuba membela nasib umat Islam yang ditindas oleh negara Barat. Namun, dalam masa yang sama mereka tidak bersetuju atau menyokong dari segi tindakan keganasan yang dilakukan oleh militan ini. Segala tindak-tanduk Daesh adalah 
bercanggah dengan syariat atau ajaran Islam seperti membunuh orang awam, membakar hidup-hidup, memotong kepala dan lain-lain lagi. Hal ini disokong oleh salah seorang responden seperti kenyataan berikut:

Pendapat tentang ISIS (Daesh) ini, dia menggunakan nama Islamik sahaja, tapi pada dasarnya dia tak ikut Islam punya undang-undang dan Islam punya syariat. Jadi dasar IS bukan dari orang Islam tapi orang bukan Islam ini hanya hendak menimbulkan perasaan orang Islam untuk berjihad dengan tinggi. Jadi mereka cucuk unsur Islam sedikit untuk menarik minat. Jadi yang terlibat ini tertipu dengan tipu helah. IS ini juga seperti yang no. 4 [responden lain] kata, tujuan untuk memecahbelahkan umat Islam. Jadi IS ini bukan tentera Islam yang betul-betul Islam dan tidak ikut langsung apa yang Islam ajar.

Hal ini jelas menunjukkan bahawa mereka yang menyokong perjuangan Daesh adalah mereka yang cetek pengetahuan agama Islam. Kebanyakan yang terlibat dan menyokong perjuangan Daesh mencarijalan singkat untuk mendapatkan balasan syurga apabila menyahut seruan jihad yang dibawa oleh Daesh dengan harapan akan mendapat mati syahid. Sebagai contoh, seorang responden berkata:

Dekat Malaysia ada dah tersebar tapi terhalang dengan media massa. Banyak media massa beritahu IS ini seleweng dan keluar dari landasan orang Islam. Dan banyak sekolah agama ustaz yang mengajar sekolah agama kata yang IS ini bukan tentera Islam yang sebenar. Tapi ada rakyat Malaysia yg sertai IS sebab seperti yang dikatakan oleh no. 2 [responden lain], pihak IS daripada timur menyuntik semangat jihad melalui internet. Jihad merupakan satu jalan untuk jalan ke syurga iaitu mati syahid. Ada orang yang baru nak up dalam agama, kenal agama, hendak mati cepat masuk syurga mati syahid. Dan mereka membawa IS membuka mata orang yang baru kenal agama ni berjihad ... kalau berjihad mati syahid. Mati syahid kira syurga. Mereka tak tahu cara pembawaan IS tu macam mana dan sertai secara semborono. Tak kaji, tak mendalami macam mana jihad itu. Rakyat Malaysia yang sertai IS tak mendalami ilmu agama secara mendalam. Kira membuta tuli dengan kata nak masuk syurga. Orang Islam target hanya satu iaitu masuk syurga tapi pelbagai cara, yang tak kenal agama tu yang paling seriau/bimbang.

Sikap tidak bersosial, enggan berguru tentang Islam dan mudah terpengaruh dengan internet juga merupakan punca rakyat Malaysia terpengaruh dengan ideologi Daesh. Mungkin dengan cara memperkenalkan berita secara atas talian boleh membantu dalam menyalurkan dan memberi persepsi bahawa Daesh berada di jalan yang salah serta mampu menolak ideologi terancang Daesh untuk mempengaruhi rakyat Malaysia (Saifuddin dan Sualman 2017). 
Pelbagai ayat al-Quran dan hadis yang dimanipulasi sehingga mempengaruhi mereka yang cetek dari segi pengetahuan agama Islam. Maka dengan ini dapatlah disimpulkan bahawa semakin tinggi ilmu pengetahuan tentang Islam seseorang itu maka semakin rendah potensi untuk mereka terpengaruh dengan ideologi dan perjuangan Daesh. Begitu juga dengan mereka yang kurang pengetahuan tentang agama Islam sangat berpotensi untuk terpengaruh dengan ideologi perjuangan Daesh terutamanya melalui media massa.

\section{KESIMPULAN}

Hasil dapatan kuantitatif dan FGD jelas menunjukkan bahawa kefahaman terhadap Daesh dan penerimaan terhadap Daesh mempunyai hubungan yang songsang. Hal ini bermaksud jika seseorang itu cetek fahaman tentang Daesh, mereka akan mudah menerima perjuangan Daesh. Perjuangan Daesh hari ini dilihat semakin berkembang dari hari ke hari dengan merekrut ahli-ahli baharu. Di Malaysia khususnya, banyak tangkapan yang dibuat terhadap golongan belia yang sanggup berjuang demi menegakkan Islam yang sebenar, padahal perjuangan yang disertai itu adalah kumpulan pengganas yang jelas terpesong daripada ajaran Islam yang sebenar. Data yang merujuk kepada kefahaman tentang Daesh ini berada di tahap terkawal kerana hampir 80\% rakyat Malaysia tahu mengenai Daesh dan ini menyukarkan penyebaran pengaruh dan sokongan mereka. Walaupun keadaan masih terkawal, kawalan ketat perlu dilaksanakan oleh kerajaan bagi membendung Daesh daripada mempengaruhi rakyat melalui media sosial (Ahmad Sauffiyan 2016).

Sungguhpun begitu, berdasarkan FGD, pihak kerajaan perlu terus memainkan peranan proaktif dengan menggunakan media sosial dalam memberi kefahaman kepada masyarakat tentang terpesongnya perjuangan Daesh daripada ajaran Islam sebenar. Kealpaan kita dalam memberi kefahaman kepada rakyat tentang Daesh akan mengakibatkan potensi terhadap penerimaan Daesh meningkat, terutamanya mereka yang tidak faham tentang agama. Kefahaman agama Islam adalah penting untuk dijadikan benteng kerana kita boleh menilai dan mampu menimbulkan kekhuatiran terhadap perjuangan Daesh. Penilaian boleh dibuat berpandukan kepada ajaran Islam yang sebenar dan secara tidak langsung rakyat Malaysia mampu menolak perjuangan Daesh tanpa melibatkan bantuan kerajaan Malaysia iaitu dengan berbekalkan kefahaman Islam yang baik cukup untuk menjadi benteng kepada penerimaan anasir-anasir luar seperti Daesh. Oleh yang demikian, terdapat beberapa langkah yang boleh dianjurkan oleh pihak kerajaan dan juga masyarakat setempat. Antaranya memperbanyakkan penyampaian e-maklumat dalam media sosial (sila lihat contoh cadangan daripada Stern dan Berger 2015) tentang Daesh di jabatan-jabatan kerajaan, institusi pengajian tinggi, 
masyarakat kejiranan dan swasta. Selain itu, perlu ada penguatkuasaan yang ketat dengan menambah bilangan anggota serta menggunakan teknologi yang canggih dalam mengesan dan menangkap ahli-ahli Daesh. Begitu juga dengan kerjasama antara sektor dalaman dan luaran negara. Kerjasama antara negara di peringkat ASEAN mahupun antarabangsa perlu dipergiatkan serta perkongsian maklumat antara negara dapat memperkuatkan lagi usaha mengekang penularan ideologi Daesh dalam kalangan rakyat.

\section{PENGHARGAAN}

Makalah ini adalah berdasarkan projek kajian yang didaftarkan di Universiti Utara Malaysia (UUM) No. S/O 13610 dengan dana yang dibiayai sepenuhnya oleh Kementerian Dalam Negeri Malaysia.

\section{RUJUKAN}

Ahmad El-Muhammady. 2016. Countering the threat of Daesh in Malaysia. In Countering Daesh extremism European and Asian responses: Panorama insights into Asian and European affairs, eds. B. Gorawantschy, R. Gunaratna, M. Sarmah and P. Rueppel, 105-122. Singapore: Konrad Adenauer Stiftung \& S. Rajaratnam School of International Studies.

Ahmad Fauzi Abdul Hamid. 2016. ISIS in Southeast Asia: Internalized Wahhabism is a major factor. ISEAS Perspective 24(2016): 1-11.

Ahmad Sauffiyan Abu Hassan. 2016. Daesh: Kebangkitan dan pengaruh media sosial. Jurnal Komunikasi Malaysian 2(2): 381-404. https://doi.org/10.17576/ jkmjc-2016-3202-20

Angkatan Tentera Malaysia. 2018. Garis panduan pencegahan fahaman ekstremism \& radikalisme dalam Angkatan Tentera Malaysia: Kami warga ATM menolak Daesh (ISIS), 25-27. Kuala Lumpur: Bahagian Staf Perisian Pertahanan ATM.

Anon. n.d. Kekeliruan umat Islam dan warga tentera tentang ideologi Daesh atau ISIS. http:// airforce.mil.my/images/PENERBITAN/ARTIKEL-2--KEKELIRUAN-UMATISLAM----DAN-WARGA-TENTERA-TENTANG-IDEOLOGI-DAESH.pdf (accessed 21 April 2018). https://doi.org/10.15642/teosofi.2013.3.2.503-525

Awan, I. 2017. Cyber-extremism: ISIS and the power of social media. Society 54(2): 138149. https://doi.org/10.1007/s12115-017-0114-0

Chan, N. 2018. The Malaysian "Islamic" state versus the Islamic State (IS): Evolving definitions of "terror" in an "Islamising" nation-state. Critical Studies on Terrorism 11(3): 415-437. https://doi.org/10.1080/17539153.2018.1447217 
Che Mohd Aziz Yaacob, Bakri Mat, Fakhrorazi Ahmad, Mohd Azizuddin Mohd Sani, Rusdi Omar and Kamarulzaman Haji Yusof. 2016. Kefahaman dan penerimaan mahasiswa universiti awam terhadap gerakan ISIS. Malaysia Journal of Youth Studies 15(7): 121-138. https://doi.org/10.11113/jt.v68.2895

Daily Sabah. 2016. Most Daesh recruits have poor knowledge on Islam. 16 August. https:// www.dailysabah.com/mideast/2016/08/16/most-daesh-recruits-have-poorknowledge-of-Islam-study-reveals (accessed 1 November 2018).

Davis, J. 2013. Evolution of the global jihad: Female suicide bombers in Iraq. Studies in Conflict and Terrorism 36(4): 279-291. https://doi.org/10.1080/105761 0x.2013.763598

Eggert, J.P. 2015. Women fighters in the "Islamic State" and al-Qaida in Iraq: A comparative analysis. Journal of International Peace and Organization 90(3-4): 363.

Farid Ridzwan. 2016. Ideologi Daesh berkait hari kiamat, sukar dipatahkan. FMT News. 14 February. http://www.freemalaysiatoday.com/category/opinion/2016/02/14/ ideologi-daesh-berkait-hari-kiamat-sukar-dipatahkan/ (accessed 7 April 2018).

Farwell, J.P. 2014. The media strategy of ISIS. Survival 56(6): 49-55.

Franco, J. 2017. Assessing the feasibility of Wilayah Mindanao. Perspectives on Terrorism 11(4): 29-38.

Hashnan Abdullah. 2016. Perangi idelologi Daesh. Utusan Online. 19 August. http://www. utusan.com.my/rencana/agama/perangi-ideologi-daesh-1.372309 (accessed 3 June 2018).

Hyder, S., N. Akram and I.Ul-H. Padda. 2015. Impact of terrorism in the economic development of Pakistan. Pakistan Business Review January: 704-722.

Jasmine Jawhar. 2016. Terrorists' use of the internet: The case of Daesh. Kuala Lumpur: SEARCCT.

Kamarulnizam Abdullah and Ahmad Ridzuan. 2019. Malaysia: Adapting to the dynamic changes of terrorist threats. In Non western responses to terrorism, ed. M.J. Boyle, 180-196. Manchester: Manchester University Press. https://doi.org/10.7228/ manchester/9781526105813.003.0005

Klausen, J. 2015. Tweeting the jihad: Social media networks of western foreign fighters in Syria and Iraq. Studies in Conflict \& Terrorism 38(1): 1-22. https://doi.org/10.10 80/1057610X.2014.974948 (accessed 25 January 2019). https://doi.org/10.1080/ 1057610x.2014.974948

Loken, M. and A. Zelens. 2018. Explaining extremism: Western women in Daesh. European Journal of International Security 3(1): 45-68.

McCants, W. 2015. The ISIS apocalypse: The history, strategy, and doomsday vision of Islamic state. New York: St Martin's Press.

Mohd Mizan Mohammad Aslam. 2017. Threat of Daesh in universities: Malaysia's experience. Counter Terrorist Trends and Analyses 9(4): 13-17.

2018. A model of deradicalization in Malaysia. In International case studies of terrorist rehabilitation, ed. R. Gunaratna and Sabariah M. Hussin. London: Routledge Taylor \& Francis.

Muhammad Saufi Hassan. 2018. Harian Metro. 42\% siswa simpati Daish. 20 October. https://www.hmetro.com.my/utama/2018/10/387895/42-siswa-simpati-daish (accessed 15 January 2019). 
MyNewsHub. 2017. Ancaman keganasan: Apakah kita di tahap merah? 10 June. https:// www.mynewshub.cc/utama-sensasi/ancaman-keganasan-apakah-kita-di-tahapmerah/ (accessed 15 January 2018).

Nacim, B. 2016. Daesh and religion values and words as weapons. The Arabic Journal of Human and Social Sciences 23: 1-17.

Osman, M.N.M. and A. Arosoaie. 2018. Jihad in the Bastion of "moderation": Understanding the threat of ISIS in Malaysia. Asia Security Online 1-14. https://doi.org/10.1080 /14799855.2018.1470508

Peresin, A. and A. Cervone. 2015. The Western Muhajirat of ISIS. Studies in Conflict \& Terrorism 38: 495-509. https://doi.org/10.1080/1057610x.2015.1025611

Portal Rasmi Polis Diraja Malaysai (PDRM). 2016. Pendekatan "counter narative" perlu dilakukan untuk tangani IS. 1 September. https://www.live4d88.com/newsdetail/2015/10/01/pendekatan-counter-narrative-perlu-dilakukan-untuk-tanganiis (accessed 8 March 2019). https://doi.org/10.31227/osf.io/ybjws

Poushter, J. 2015. In nations with significant Muslim populations, much disdain for ISIS. 17 November. http://www.pewresearch.org/fact-tank/2015/11/17/in-nationswith-significant-Muslim-populations-much-disdain-for-isis/ (accessed 6 February 2018).

Rahimin Affandi Abdul Rahim, Mohd Anuar Ramli, Mohd Imran Abdul Razak, Muhammad Ikhlas Rosele and Siti Maimunah Kahal. 2016. Menangani fenomena ekstremisme agama mengikut perspektif maqasid syariah. In Maqasid AlShari'ah: Aplikasi dalam aspek sosial dan perundangan, eds. Rahimin Affandi Abdul Rahim, Mohd Anuar Ramli and Shahidra Abdul Khalil, 101-128. Kuala Lumpur: Akademi Pengajian Islam, Universiti Malaya. https://doi.org/10.18592/ al-banjari.v16i1.975

Samuel, T.K. 2012. Reaching the youth: Countering the terrorist narrative. Kuala Lumpur: SEARCCT.

2019. Undergraduate radicalisation in selected countries in SEA. Kuala Lumpur: SEARCCT. http://www.searcct.gov.my/images/Articles_2016/Articles_2018/ Undergraduate_Radicalisation_in_Selected_Countries_in_SEA.pdf (accessed 15 January 2019).

Saifuddin, N. and I. Sualman. 2017. The portrayal of Islamic state in selected online newspapers in Malaysia: A framing approach. Journal of Media and Information Warfare 9: 101-136.

Schulze, K.E. and J.C. Liow. 2018. Making jihadis, waging jihad: Transnational and local dimensions of the ISIS phenomenon in Indonesia and Malaysia. Asian Security https://doi.org/10.1080/14799855.2018.1424710

Singh, B. 2018. Terrorist networks in Southeast Asia and implications for regional security. Counter Terrorist Trends and Analysis 10(5): 8-10.

Small, T. and J. Hacker. 2015. Path of blood: The story of al-Qaeda war on Saudi Arabia. New York: Harry N. Abrams.

Spencer, A.N. 2016. The hidden face of terrorism: An analysis of the women in Islamic State. Journal of Strategic Security 9(3): 74-98.

Stern, J. and J.M. Berger. 2015. ISIS: The state of terror. New York: Harper Collins. 
The Guardian. 2019. ISIS defeated, US-backed Syrian democratic forces announce. 23 March. https://www.theguardian.com/world/2019/mar/23/isis-defeated-usbacked-syrian-democratic-forces-announce (accessed 8 April 2019).

Utusan Online. 2017. PDRM patahkan rancangan Daesh, tahan perancang utama warga Filipina. 5 September. https://www.utusan.com.my/berita/nasional/pdrmpatahkan-rancangan-daesh-tahan-perancang-utama-warga-filipina-1.523219 (accessed 13 January 2018).

2017. 346 ditahan terlibat DAESH. 23 October. http://www.utusan.com.my/berita/ nasional/346-ditahan-terlibat-daesh-1.541527 (accessed 13 November 2017).

Wan Fariza Alyati Wan Zakaria. 2017. Daesh, jihad dan wanita: Sensasi dan manipulasi atas nama agama. Siri Wacana Tun Fatimah Hashim Bil 1/2017, Graduate School of Business, Universiti Kebangsaan Malaysia. 27 July. https://doi.org/10.21315/ $\mathrm{km} 2017.35 .1 .5$

Warrick, J. 2015. Black flags: The rise of ISIS. New York: Anchor Books.

Weiss, M. and Hassan, H. 2015. ISIS: Inside the army of terror. New York: Regan Arts. Wrights, L. 2017. The terror years: From al-Qaeda to Islamic State. New York: Vintage. Zulkarnain Haron. 2016. Melawan naratif-naratif IS/ISIS/Daesh. Berita Tentera Darat Malaysia. 25 March. https://btdmonline.net/2016/03/melawan-naratif-naratifislamic-state-di-iraq-dan-syria-isis-a-k-a-ad-dawla-al-islmiyya-fi-iraq-wa-ashsham-daesh-apa-yang-perlu-anda-ketahui-dan-bagaimana-melawan-naratifnaratif-tersebut/ (accessed 31 July 2019). 